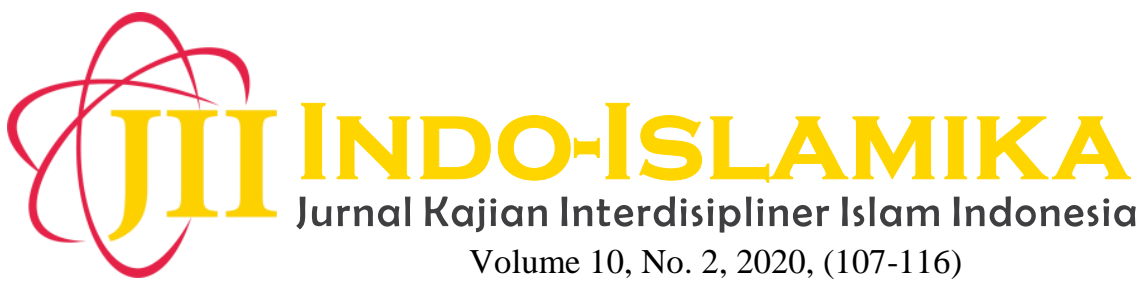

Sekretariat : Graduate School Syarif Hidayatullah State Islamic University (UIN) Jakarta

Website OJS : http://journal.uinjkt.ac.id/index.php/indo-islamika/index E-mail : indoislamika@uinjkt.ac.id

\title{
Kontribusi Pendidikan Islam Modern di Indonesia: Studi Kasus Pesantren Riyadlul Ulum Wadda'wah, Condong, Tasikmalaya
}

\author{
Dewi Aprilia Ningrum, Rifa Tsamrotus Sa'adah \\ UIN Syarif Hidayatullah Jakarta, Indonesia, Indonesia \\ Corresponding E-mail: dewiapriliyaningrum95@gmail.com
}

\begin{abstract}
This study discusses Riyadlul Ulum Wadda'wah Condong Islamic boarding school's best practice in learning foreign languages and adopting modern values in its education management system. The experience of this Islamic Boarding School which is known also as Pondok Pesantren Condong, Tasikmalaya, is considered important to be shared to others due to its new policy which blended three existing education systems in the country in spite of the fact that many scholars have overlooked it. The boarding school retained the curriculum of traditional pesantren, adopts the modern Islamic boarding school system of Darussalam Gontor, and applies also general education systems for junior and senior high school system. Using a descriptive-analytic method, this study examines how Condong Islamic Boarding School carried out its modernization program both in learning foreign languages (Arabic and English language) and in coverging three models of education -curriculum of traditional pesantren, Darussalam Gontor's modern, and general education system for its education program and governance. In so doing, the main data of the study were collected from observation and experience of the writers while $i$ was a student of this pesantren for six years 2007-2012. The study finds that Condong Islamic Boarding School has successfully transformed its boarding school from passive traditional Islamic boarding school to progressive and modern one. It also finds that the application of new learning foreign languages and of modern values in Condong Islamic boarding school affects significantly to the progress and transformation of students to achieve their and the school's expected outcomes.
\end{abstract}

Keywords: Contribution, Education, Pesantren, Modern, Indonesia.

\begin{abstract}
Abstrak
Penelitian ini membahas best practice Pondok Pesantren Riyadlul Ulum Wadda'wah Condong dalam pembelajaran bahasa asing dan mengadopsi nilai-nilai modern dalam sistem manajemen pendidikannya. Pengalaman Pesantren yang juga dikenal dengan Pondok Pesantren Condong, Tasikmalaya ini dianggap penting untuk dibagikan kepada orang lain karena kebijakan barunya yang memadukan tiga sistem pendidikan yang ada di tanah air meskipun banyak ulama yang mengabaikannya. Itu. Pesantren tersebut tetap mempertahankan kurikulum pesantren tradisional, mengadopsi sistem pesantren Darussalam Gontor modern, dan menerapkan juga sistem pendidikan umum untuk sistem SMP dan SMA. Dengan menggunakan metode deskriptif-analitik, penelitian ini mengkaji bagaimana Pondok Pesantren Condong melaksanakan program modernisasinya baik dalam pembelajaran bahasa asing (bahasa Arab dan bahasa
\end{abstract}


Inggris) maupun dalam mencakup tiga model pendidikan - kurikulum pesantren tradisional, modern Darussalam Gontor, dan umum. sistem pendidikan untuk program pendidikan dan pemerintahannya. Dalam pelaksanaannya, data pokok penelitian dikumpulkan dari observasi dan pengalaman penulis selama menjadi santri di pesantren ini selama enam tahun 2007-2012. Studi ini menemukan bahwa Pondok Pesantren Condong telah berhasil mengubah pesantrennya dari pesantren tradisional pasif menjadi pesantren progresif dan modern. Penelitian ini juga menemukan bahwa penerapan pembelajaran baru bahasa asing dan nilai-nilai modern di pondok pesantren Condong berpengaruh secara signifikan terhadap kemajuan dan transformasi peserta didik untuk mencapai hasil yang diharapkan dan mereka sekolah.

Kata Kunci: Kontribusi, Pendidikan, Pesantren, Modern, Indonesia.

\section{PENDAHULUAN}

Pesantren merupakan bagian dari bukti sejarah Islam di Indonesia. Pesantren adalah lembaga pendidikan Islam yang indigeneous dan geneuine (khas-asli) indonesia, bahkan menurut KH. Imam Zarkasyi, pendidikan di Pondok itulah yang sebenarnya pendidikan nasional sejati, yang tulen, pure nasional. Pendidikan pesantren sudah eksis dan mapan jauh hari sebelum munculnya sekolah-sekolah dan telah terbukti mempunyai peran besar terhadap penyebaran Islam, pendidikan keagamaan, transmisi keilmuan, pemeliharaan tradisi keislaman, penyiapan kader ulama dan pejuang di masyarakat.

Menurut Ahmad Zarkasyi pondok pesantren adalah lembaga pendidikan agama Islam dengan bersistem asrama atau pondok, yaitu seorang kyai menjadi figur utama yang penting, masjid sebagai pusat kegiatan pada setiap harinya, dan sistem pengajaran agama Islam yang dibimbing langsung oleh kyai yang diikuti oleh para santri. ${ }^{1}$ Pengertian yang dikutip oleh KH.Imam Zarkasyi tersebut lebih komprehensif, karena mempunyai beberapa kelebihan dari definisi lainnya, yakni : 1) Pesantren harus berbentuk asrama (full residential Islamic Boarding School), 2) fungsi kyai sebagai central figure (uswah hasanah) yang berperan sebagai guru (mu'allim), pendidik (murabbi), dan pembimbing (mursyid), dan 4) materi yang diajarkan tidak terbatas kepada kitab kuning saja.

Menurut Yacub, pesantren berarti sebuah lembaga pendidikan Islam yang umumnya dengan cara non-klasikal, pengajarnya seorang yang mempunyai ilmu agama Islam melalui kitab-kitab agama Islam klasik (kitab kuning) dengan tulisan Arab dalam bahasa Melayu kuno atau dalam Bahasa Arab. Kitab-kitab itu adalah hasil karya ulamaulama Islam (Arab) dalam zaman pertengahan. ${ }^{2}$ Zamakhsyari Dhofier juga menyebutkan pesantren itu terdiri dari lima unsur pokok yaitu: kyai, santri, masjid, pondok, dan pegajaran kitab-kitab Isam klasik. ${ }^{3}$ Kelima elemen tersebut merupakan ciri khusu yang dimiliki pesantren dan membedakan pendidikan pondok pesantren denga lembaga pendidikan dalam bentuk lain. Sekalipun kelima elemen ini saling menunjang eksistensi sebuah pesantren, akan tetapi kyai memainkan peranan yang begitu sentral di dunia pesantren.

Berbicara tentang keunggulan didalamnya, pendidikan pesantren telah diakui para pakar dan tokoh pendidikan nasional di antaranya adalah Ki Hajar Dewantoro dan juga Dr. Soetomo yang mencita-citakan pesantren sebagai model sistem pendidikan

${ }^{1}$ Zamakhsyari Dhofier, Tradisi Pesantren: Studi tentang Pandangan Hidup Kyai (Jakrta:LP3ES, 1984), 19.

2 Muhammad Yacub, Pondok Pesantren dan Pengembangan Masyarakat Desa (Bandung:Angkasa,1993), 65.

${ }^{3}$ Zamakhsyari Dhofier, Tradisi Pesantren: Studi tentang Pandangan Hidup Kyai,18 
nasional Indonesia karena keunggulan pendidikanya yang konfrehensif dan integratif, baik sisi kognitif, efektif maupun psykomotoric. Banyak ulama pejuang dan tokoh masyarakat telah dilahirkan oleh pesantren, secara umum mereka telah menjadi panutan dan taulandan yang baik, mandiri atau mampu memberi kontribusi nyata diberbagai bidang kehidupan masyarakat. ${ }^{4}$

Pesantren mampu bertahan hingga saat bahkan mengalami perkembangan signifikan karena tetap mempertahankan jiwa, ruh, spirit dan nilai-nilai filosofis pendidikanya, tidak kehilangan visi misi dan orientasi perjuangannya. Pesantren juga mempunyai sistem pendidikan asrama yang berdisiplin sebagai perpaduan ideal dari catur pusat pendidikan (pendidikan keluarga, sekolah, masyarakat dan masjid sebagai pusat miliu yang menjiwai). Pesantren juga mempunyai program, strategi dan materi kurikulum pendidikan 24 jam, baik intra, ekstra maupun kurikuler sebagai implementasi dari tujuan pendidikannya. ${ }^{5}$

Azyumardi Azra juga menegaskan bahwa pesantren yang ada saat ini terus merapihkan dan mendalami diri, dan juga berbagai perkumpulan yang merangkul komponen positif di dalam pesantren. Pesantren mendorong rasa syukur yang benar untuk semua kemajuan yang terjadi di masa kini dan yang akan datang. Adapun bebearapa unsur logika pesantren dipersepsikan oleh Azra sebagai kapasitas kelembagaan memiliki tiga tugas pokok diantaranya transmisi kajian keilmuan Islam, menjaga secara utuh tradisi Islam dan meningkatkan kualitas calon-calon ulama yang akan datang. Azra mengungkapkan bahwa keilmuan pesantren mengatur pengembangan informasi, bukan peningkatan informasi. Hal ini dapat ditemukan dalam konvensi pesantren yang pada umumnya akan mengatur perubahan logika di pesantren. ${ }^{6}$

Hal ini membuktikan bahwa tradisi pesantren memiliki asosiasi dan pengetahuan tentang jejaring alam yang sangat diperlukan untuk membuat langkah pendidikan lanjutan yang mencangkup seluruh warga negara. Dengan begitu hal ini dibuat pembelajaran, sehingga ada hubungan yang saling melengkapi antara keduanya. ${ }^{7}$ Masyarakat mulai tertarik pada pelatihan di pesantren, sehingga pesantren dapat memahami masakah yang dilihat oleh jaringan untuk menemukan pengaturan elektif.

\section{METODE}

Jenis penelitian dalam penelitian ini adalah deskriptif analitik ditambah dengan pengalaman salah satu penulis yang pernah mengenyam di pesantren Riyadlul Ulum Wadda'wah Condong Tasikmalaya. Penulis mengumpulkan beberapa data dengan melakukan wawancara dan mengambil sumber dari beberapa pustaka seperti buku, media sosial, dan bentuk tulisan lain yang dianggap relevan dan sesuai dengan tema pembahasan. Dengan menggunakan metode deskriptif kualitatif, penulis menemukan hasil data apa adanya tanpa adanya suat proses memanipulasi atau hal lain yang merusak penelitian ini. Dengan pendekatan demikian, penulis mencoba melihat bagaimana fenomena atau kenyataan sosial yang telah dialami oleh pesantren Condong dalam menerapkan sistem modern di lembaga pesantren ini.

4 Ahmad Suharto, Melacak Akar Filosofis Pendidikan Gontor, (Kajian Metaforis Syajarah Thayyibah Gontor) (Yogyakarta: Namela, 2017), 9

${ }^{5}$ Suharto, Melacak Akar Filosofis Pendidikan Gontor, 10.

${ }^{6}$ Azyumardi Azra, Esai-Esai Intelektual Muslim Pendidikan Islam (Jakarta : Logos Wacana Ilmu, 1999), 89.

${ }^{7}$ Azra, Esai-Esai Intelektual Muslim Pendidikan Islam, 108. 


\section{HASIL DAN PEMBAHASAN}

\section{Sejarah Pesantren di Indonesia}

Pesantren sebagai lembaga pendidikan Islam yang sangat penting dan menarik, khususnya bagi praktisi pendidikan dan pemimpin umat. Pesantren memiliki peran, fungsi, dan kontribusi sebagai lembaga pendidikan Islam dan dakwah Islam dalam mewujudkan masyarakat madani di Indonesia. Pesantren sebagai lembaga pendidikan tetap dan konsisten melakukan perannya sebagai pusat pendalaman ilmu-ilmu agama yang ikut ikut serta mencerdaskan bangsa telah diakui masyarakat.

Menurut Herman mengutip pendapat Muhammad Daud Ali, dalam bukunya menyatakan bahwa pondok pesantren bermula dari seorang kyai yang menetap (bermukim) disuatu tempat. Kemudian datanglah santri yang ingin belajar kepadanya dan di luar. Sebagian para santri ada juga yang bermukim di dalamnya Untuk biaya kehidupan dan Pendidikan disediakan Bersama-sama oleh para santri dengan dukungan masyarakat sekitar. Pertama kali pondok pesantren di kenal di Indonesia pada masa Walisongo, pada masa itu pesantren menjadi tempat berlangsungnya interaksi antara guru dan murid dalam mentransfer ilmu-ilmu keislaman dan pengalaman. ${ }^{8}$

Ahmad Muhakamurrohman mengungkapkan bahwa sejarah pesantren di Indonesia pada abad ke-16 M, bertepatan di Ampel Denta dalam asuhan Sunan Ampel. Sunan Ampel mendirikan sebuah pesantren di Ampel Surabaya dan menjadikan pusat Pendidikan di Jawa. Pesantren Ampel yang didirikan oleh Syaikh Maulana Malik Ibrahim, merupakan cikal bakal berdirinya pesantren-pesantren di Tanah Air sebab para santri merasa berkewajiban mengamalkan ilmunya di daerahnya masing-masing. Bahkan Sebagian para santri ada yang berasal dari Gowa dan Tallo, Sulawesi saat itu. ${ }^{9}$ Puncaknya adalah pada awal pertengahan abad ke-19 serta awal abad ke-20, yaitu pada masa Syekh Khalil Bangkalan. Dari tangan beliaulah muncul kyai besar Nusantara. ${ }^{10}$

Dalam penelusuran sejarah juga membuktikan bahwa cikal-bakal Pendidikan pesantren pada periode awal ini terdapat di daerah-daerah sepanjang pantai Jawa, seperti Giri (Gresik), Ampel Denta (Surabaya) Bonang (Tuban) Kudus, Lasem, Cirebon, dan sebagainya. ${ }^{11}$ Kendati demikian, pesantren memiliki umur yang sama tuanya dengan Islam di Indonesia. Ia menjadi salah satu media dalam menyebarluaskan Islam dan berdampak besar dalam perubahan sosial masyarakat Indonesia. Pesantren terbentuk melalui proses yang panjang yang diawali oleh terbentuknya kepemimpinan dalam masyarakat. Seorang kyai tidaklah muncul begitu saja, kyai harus mendapatkan pengakuan oleh masyarakat, dan dianggap memiliki keutamaan ilmu. ${ }^{12}$

Dalam penelitian yang ditulis oleh Hasan, tahapan awal pembentukan pesantren awalnya sebagai masjid pusat pendidikan bagi masyarakat. Masjid menjadi tempat kegiatan pembelajaran dilakukan. Seiring dengan berkembangnya zaman, pesantren dilengkapi dengan pondok atau tempat tinggal santri. Tidak sedikit masyarakat ikut membantu secara sukarela bahkan mewakafkan tanahnya, dan bantuan tenaga. Hal

\footnotetext{
${ }^{8}$ Herman, "Sejarah Pesantren di Indonesia," Jurnal Al-Ta'dib 6, 2 (2013): 148.

${ }^{9}$ Herman, "Sejarah Pesantren di Indonesia," 149.

${ }^{10}$ Ahmad Muhakamurrohman, "Pesantren: Santri, Kiai, dan Tradisi," Jurnal Kebudayaan Islam 12, 2 (2014): 112.

11 Imam Syafe'i, "Pondok Pesantren: Lembaga Pendidikan Pembentukan Karakter," $A l$ Tadzkiyyah: Jurnal Pendidikan Islam 8, 1 (2017): 65.

${ }^{12}$ Herman, "Sejarah Pesantren di Indonesia," 150.
} 
itulah yang masih berlaku hingga saat ini di pesantren. ${ }^{13}$

Banyak yang menilai bahwa pesantren adalah suatu lembaga pendidikan agama Islam dalam bidang statis. Penilaian tersebut tidak dianggap keliru meski tidak seluruhnya benar. Pendidikan dalam pesantren bisa dianggap benar jika dikaji secara konseptual. Walaupun Pendidikan di pesantren seluruhnya tidak hanya berbicara mengenai konsep, pendidikan pesantren akan selalu mengalami dialektika.Pendidikan pesantren tetap mengalami konteks yang selalu berubah dan mengalami dinamika dari masa ke masa.

Selanjutnya, mengenai dialektika pesantren yang sudah menjalar di Indonesia, Abdul Munir Mulkhan mengungkapkan bahwa tujuan adanya dialektika di pesantren sangat membantu masyarakat dalam menumbuhkan swadaya. Pesantren di lingkungan masyarakat menjadi Pendidikan formal jalur sekolah yang dikembangkan pemerintah sebagai Pendidikan yang moderat, bebas, kreatif dan lain-lain. ${ }^{14}$ Azra mengungkapkan bahwa Perjalanan pendidikan Islam tradisional khususnya pesantren telah begitu panjang. Ketika arus globalisasi telah membawa perkembangan sosial kultur masyarakat yang semakin maju, maka tak heran ketika problem yang dialami pesantren sebagai pendidikan semakin kompleks". ${ }^{15}$

\section{Respon Pesantren Terhadap Globalisasi}

Mengungkap makna globalisasi, ia berawal dari kata 'global' yang berarti mengindikasikan bahwa dunia menjadi sebuah kontinuitas lingkungan yang telah terkonstruksi sebagai kesatuan utuh. Globalisasi menjadikan dunia dan sekitarnya menjadi transparan, karena ilmu pengetahuan dan teknologi informasi. Menurut Umma Farida dalam penelitianya bahwa globalisasi juga merupakan istilah yang digunakan untuk menggambarkan proses multilapis dan multidimensi dalam realitas kehidupan yang sebagaian besar dikonstruksi oleh Barat. Farida menyatakan bahwa dengan adanya globalisasi juga terjadi pertemuan dan gesekan nilai-nilai budaya dan agama di seluruh dunia. ${ }^{16}$ Hal ini mempengaruhi kondisi masyarakat untuk saling bertentangan dan bertabrakan dengan nilai-nilai yang ada.

Proses saling mempengaruhi tersebut menjadikan suatu peradaban, budaya dan agama dipengaruhi oleh unsur-unsur yang lain. Hal ini menimbulkan suatu idiologi baru yang tidak sesuai dengan kulturnya, dan ini juga dialami oleh lembaga pendidikan Islam seperti pesantren. Walaupun globalisasi mempengaruhi sebuah idiologi, hal ini bisa mengandung hal-hal positif ketika idiologi tersebut dimanfaatkan dengan tujuan yang baik. Sebaliknya, idiologi akan berakibat negatif jika dipergunakan untuk tujuan yang negatif.

Dapat kita lihat bahwa paradigma yang berkembang di kalangan umat Islam dalam menghadapi globalisasi ada tiga yaitu: pertama, konservatif. Paradigma ini memiliki pemikiran atau tradisi lama yang belum bersentuhan dengan wacana keilmuan

\footnotetext{
${ }^{13}$ Herman, "Sejarah Pesantren di Indonesia," 51.

14 Abdul Munir Mulkhan, Nalar Spiritual Pendidikan, Solusi Problem Filosofis Pendidikan Islam (Yogyakarta: PT. Tiara Wacana Yogya, 2002), 180

15 Azyumardi Azra, Surau, Pendidikan Islam Tradisional Dalam Transisi dan Modernisasi (Jakarta: Logos Wacana Ilmu, 2003), 41.

${ }^{16}$ Umma Farida, "Radikalisme, Moderatisme, Dan Liberalisme Pesantren:Melacak Pemikiran dan Gerakan Keagamaan Pesantren di Era Globalisasi," Edukasia: Jurnal Penelitian Pendidikan Islam 10, 1 (2015): 147.
} 
selain Islam. Menurut kalangan konservatif menganggap bahwa globalisasi merupakan unsur yang sangat mengancam bagi keberlangsungan nilai-nilai Islam. Kedua, liberal. Pesantren menurut paradigm ini yaitu Islam adalah agama yang dapat berperan sebagai agen perubahan sosial. Karena paradigma liberal ini mengedepankan aspek rasionalisme, maka pemahaman cenderung terlalu kontekstual sehingga tidak memperdulikan pemahaman tekstualitas dan latar belakang munculnya pemahaman agama Islam. Ketiga, Moderat. Paradigma ini terkenal dalam konsep Islam sebagai agama wasathan. Ia mencoba untuk mempersatukan pemahaman keduanya dengan cara membuat pertimbangan mengenai Islam selalu mempunyai kaitan atau hubungan yang tak terpisahkan dengan masalah-masalah masyarakat. Selain itu, ia bisa berkompromi dengan kaum liberal dengan tetap memperhatikan nilai-nilai luhur Islam. ${ }^{17}$ Tiga paradigma di atas dapat dipahami bahwa globalisasi dapat juga memunculkan wacana baru dalam berbagai lapangan kehidupan literatur akademik, media massa, forum-forum seminar, diskusi, dan pembahasan dalam berbagai lembaga.

\section{Pesantren Riyadlul Ulum Wadda'wah Condong Dan Dinamika Kemodernan Pendidikan Islam}

Istilah Modern atau Modernisasi lebih dikenal sebagai_suatu proses transformasi dari suatu perubahan ke arah yang lebih maju atau meningkat di berbagai aspek dalam kehidupan masyarakat. Secara sederhana, dapat dikatakan bahwa modernisasi adalah proses perubahan dari cara-cara tradisional ke cara-cara baru yang lebih maju dalam rangka untuk peningkatan kualitas hidup masyarakat. Sebagai suatu bentuk perubahan sosial, modernisasi biasanya merupakan bentuk perubahan sosial yang terarah dan terencana. Perencanaan sosial (social planning) dewasa ini menjadi ciri umum bagi masyarakat atau negara yang sedang mengalami perkembangan. Suatu perencanaan sosial haruslah didasarkan pada pengertian yang mendalam tentang bagaimana suatu kebudayaan dapat berkembang dari taraf yang lebih rendah ke taraf yang lebih maju atau modern. ${ }^{18}$

Menurut Nurcholish Madjid, konsep modernisasi pesantren sebagai suatu alternatif pembentukan masyarakat madani dan menjadi suatu lambang pendidikan Islam yang mempunyai corak khusus yang berbeda dengan lembaga pendidikan lain. Komitmen Nurcholish Madjid dalam memodernisasi dunia pendidikan Islam Indonesia adalah kemodernan yang dibangun dan berakar dari kultur Indonesia serta dijiwai semangat keimanan. Maka untuk merekontruksi institusi pendidikan tersebut perlu mempertimbangkan sistem pesantren yang mempertahankan tradisi belajar "kitab-kitab klasik" ditunjang dengan upaya internalisasi unsur keilmuan modern. ${ }^{19}$

Hal ini selaras dengan penelitian kami di pesantren Riyadlul Ulum Wadda'wah Tasikmalaya atau akrab disebut-sebut pesantren Condong. Pesantren ini konsisten menerapkan tiga kurikulum sekaligus dengan berpegangan kepada sebuah prinsip alMuhafazhah 'ala al-qadim al-salih wa al-akhdzu bi al-jadid al-ashlah. Tiga kurikulum tersebut berikut kurikulum tradisional, kurikulum pondok pesantren Modern Darussalam Gontor, dan Pendidikan Umum. Pada awalnya pesantren ini hanya

17 Umma Farida, "Radikalisme, Moderatisme, Dan Liberalisme Pesantren:Melacak Pemikiran dan Gerakan Keagamaan Pesantren di Era Globalisasi," 149-150.

18 Abdullah Syukri Zarkasyi, Gontor dan Pembaruan Pendidikan Pesantren (Jakarta: Raja Grafindo Persada 2005), 133

${ }^{19}$ Nurcholish Madjid, Modernisasi Pesantren (Jakarta: Mekarjaya 2001), 133. 
mengajarkan kitab kuning, hingga sudah banyak alumninya yang menjadi pejuang penyebar agama di berbagai daerah yang datang dari pelosok nusantara dan luar negeri , diantaranya Jawa Barat, Banten, DKI, Jawa Tengah, Jawa Timur, Aceh, Kalimantan, Sumatra, Sulawesi, NTT, Papua, Singapura, Malaysia.

Pesantren Condong memiliki sejarah dengan peristiwa 26 Desember 1996 di Tasikmalaya. Salah satunya seorang ustad yang bernama Mahmud Farid, putra pimpinan pesantren yang menjadi korban kekerasan oknum polisi yang menjadi dampak kemarahan masyarakat sekitar. Awalnya, pesantren ini hanya madrasah yang ditempati oleh santri dalam maupun luar. Semenjak Mahmud mengajar di pesantren Condong, ia menerapkan sistem hukuman yang sama dengan pesantren Darussalam Gontor. Beberapa masyarakat tidak rela dan memberikan argumentasi yang buruk terhadap Mahmud. Mahmud dituduh melakukan kekerasan fisik kepada para santri Condong dan dianggap tidak layak diterapkan di lembaga pesantren. Mahmud dibawa oleh beberapa oknum polisi dan diasingkan di kantor kepolisian Tasikmalaya. Mahmud mengaku bahwa dirinya mendapat banyak perlindungan dari beberapa guru pesantren di jawa barat hingga ia terbebas dari penjara. ${ }^{20}$

Sejak tahun 1985, pondok pesantren ini sudah mulai memadukan kurikulum pondok pesantren dengan kurikulum Gontor, dan sejak tahun 2001 Condong mulai mengkolaborasikan dengan kurikulum pendidikan Nasional, yaitu SMP Terpadu. Dimulai pada tahun 2003-2004 dibuka SMA Terpadu dengan program lanjutan dari SMA Terpadu dan Program Intensif (SMP dari luar). Sama seperti halnya SMP Terpadu, SMA Terpadu juga paduan dari kurikulum Pendidikan Nasional, Kurikulum Pondok Pesantren dan kurikulum Gontor. Adanya penggabungan tiga kurikulum ini tidak langsung melesat secara langsung, melainkan membutuhkan proses yang amat sangat panjang. Dimulai tahun 2003-2004, dibangunlah SMA Terpadu dengan program lanjutan dari SMA Terpadu dan Program Intensif (SMP dari luar). Sama seperti halnya SMP Terpadu, SMA Terpadu merupakan paduan dari kurikulum Pendidikan Nasional, Kurikulum Pondok Pesantren dan kurikulum Gontor.

Salah satu faktor yang mengakibatkan keterlambatan ini adalah adanya problemalisasi yang terjadi antara dewan pengurus Pondok Modern Gontor dan dewan pengurus Pondok salaf. Hampir semua kegiatan pengaplikasian dari Pondok Gontor menjadikan deskriminasi pengajaran pondok salaf. Ini sangat wajar, karena Condong baru memulai hangat dengan system terpadu. Salah satu contohnya adalah Panggung Gembira atau lebih akrab dengan pentas santri, kegiatan ini memicu konflik adi kalangan dewan salaf dan hampir menjadi sorotan negatif masyarakat. ${ }^{21}$

Seiring berjalannya waktu, kurikulum Modern Gontor menjadi unggul dan berpengaruh terhadap akreditasi Pondok Pesantren Condong. Pembaruan metode kurikulum pengajaran ini dilakukan secara efisien. Meskipun kurikulum ini menjadi yang teratas, Pondok Pesantren Condong sama sekali tidak mendeskriminasi pembelajaran Pesantren Salaf yang telah diterapkan terlebih dahulu. Pembelajaran Salaf dikaji dalam dua waktu, yaitu saat KBM di kelas dan sorogan jama'ah setelah maghrib. Sangat wajar, jika sebagian dari santri Condong merasa terbebani dengan penggabungan

20 Mahmud Farid, Wawancara di Pesantren Riyadlul Ulum Wadda'wah Tasikmalaya, (Tasikmalaya, 25 April 2020).

${ }^{21}$ Diding Darul Falah, Wawancara Tentang Sejarah Pesantren Condong di Pondok Pesantren Riyadlul Ulum Wadda'wah, ( 25 April 2020). 
tiga kurikulum ini. Semua ini diterapkan untuk kemaslahatan santri agar menjadi ulama yang intelektual dan memiliki sikap yang dinamis. ${ }^{22}$

Oleh karena itu, kurikulum terkait Pendidikan Islam di Pesantren Condong mencakup semua kegiatan dalam berbagai bentuknya. Semua ini merupakan satu kesatuan kurikulum yang tak terpisahkan dan mengatur seluruh kehidupan santri guna untuk mencapai tujuan pendidikan dan pengajaran yang dikehendaki. Dengan kata lain, totalitas kegiatan yang ada memiliki nilai pendidikan dalam berbagai aspeknya, sehingga segala yang dilihat, didengarkan, dirasakan, dan dialami oleh santri adalah untuk pendidikan. ${ }^{23}$

Pesantren diharapkan dapat memberikan responsi atas tuntutan era mendatang yang meliputi dua aspek, universal dan nasional. Aspek universal yaitu ilmu pengetahuan dan teknologi. Sedangkan dalam skala nasional yaitu pembangunan di Indonesia. Bahkan pesantren memiliki peran besar dalam menentukan suatu pola pembangunan yang bersifat "indigenous", merupakan asli sesuai aspirasi bangsa Indonesia sendiri, karena pesantren adalah sebuah lembaga sistem pendidikanpengajaran yang paling besar dan mengakar kuat. ${ }^{24}$

\section{Bilingual Language (Dua Bahasa) Sebagai Pengaruh Kemodernan di Pesantren Riyadlul Ulum Wadda'wah Condong}

Pesantren Condong yang dikenal sebagai pesantren modern tentu memiliki beberapa moto atau falsafah hidup didalamnya. Namun, meski tidak lepas dari istilah modern, Condong tetap berbekal nilai mengacu kepada khazanah dunia pesantren, namun dilakukan secara efektif dan efisien mengadopsi sistem pendidikan modern. Ada lima jiwa yang diterapkan oleh pesantren Condong bagi para santrinya, yaitu:

Pertama, Jiwa keikhlasan. Hal ini dibuktikan dengan keikhlasan para guru dalam mendidik, para santri ikhlas untuk dididik dalam menjalankan proses pendidikan. Kedua, Jiwa kesederhanaan. Sederhana bukan berarti pasif, bukan pula miskin atau melarat. Kesederhanaan diartikan sebagai nilai-nilai kekuatandan penguasaan diri dalam menghadapi perjuangan hidup.

Ketiga, Jiwa berdikari. Pesantren diharapkan menjadi lembaga pendidikan yang sanggup berdikari, sehingga ia tidak menyandarkan kelangsungan hidupnya kepada bantuan atau belas kasihan pihak lain. Keempat, jiwa Ukhuwah Diniyyah (persaudaraan keagaman). Kehidupan di pondok pesantren diliputi suasana persaudaraan yang akrab, segala suka dan duka dirasakan bersama dalam jalinan persaudaraan sebagai sesama Muslim. Ukhuwwah ini bukan saja selama mereka di dalam pondok, tetapi juga mempengaruhi kearah persatuan umat dalam masyarakat.

Kelima, Jiwa bebas. Santri diberikan kebebasan dalam berfikir dan bertindak. Kebebasan yang masih dalam garis yang positif dan baik dalam kehidupan pesantren itu sendiri ataupun di luar masyarakat. Kebebasan ini selalu didasarkan dalam kehidupan ajaran-ajaran agama yang benar dilandaskan kepada Al-Quran dan Sunnah.

Lima panca jiwa diatas telah diterapkan oleh pesantren Condong dan jiwa kelima menjadi sebab adanya sebutan modern untuk pesantren ini. Salah satu contoh jiwa kebebasan di pesantren condong ialah dengan penerapan bilingual language (dua bahasa). Awalnya, bahasa dianggap sebelah mata karena perannya hanya sebagai bahasa asing dan hanya diperlajari di sekolah saja. Condong melakukan kebijakan

\footnotetext{
${ }^{22}$ Santri Condong, Majalah Condong (Tasikmalaya: Condong Press, 2004), 23.

${ }^{23}$ Abdullah Syukri Zarkasyi, Gontor dan Pembaruan Pendidikan Pesantren,133.

${ }^{24}$ Nurcholish Madjid, Modernisasi Pesantren, 133
} 
dengan mengikuti ajaran Darussalam Gontor dengan menggunakannya di lingkungan pesantren.

Seluruh Asatidz (para pengajar) dan Thullab (para murid) berperan aktif selama pembelajaran yang menuntut untuk memakai dua bahasa ini. Sebagian ada yang menguasai dalam satu bahasa saja, ada sebagian yang menguasai akan keduanya. Pengajaran yang ada di pondok ini menjadi pelopor terbaik di kalangan pesantren khususnya di Tasikmalaya, karena mereka masih menggunakan bahasa lokal Sunda. Oleh karena itu, sangat wajar sebagian santri masih kaku karena hal ini, tetapi semua ini tetap dilaksanakan secara tertib dan maksimal.

Penggunaan dua bahasa ini sangat membantu para santri untuk meningkatkan keaktifan mereka dalam berbahasa khususnya dalam speaking. Para guru berusaha untuk meningkatkan bahasa mereka dengan melakukan training sebelum mengajar di kelas dengan para pengurus senior di bidang bahasa. Tentunya, hal ini sangat unik dan menjadi sorotan sekolah lainnya walaupun proses komunikasi antara guru dengan murid memerlukan waktu yang lama. Adapun kekurangan yang penulis dapatkan adalah penggunaan bahasa yang disampaikan oleh para guru terkadang kurang sesuai dengan arti kebahasaan dalam bahasa arab dan inggris, sehingga sedikit dari para murid yang mampu menguasai literature kebahasaan dengan baik dan benar. ${ }^{25}$

Bahasa memang telah menjadi asupan terbaik bagi santri Condong. Selain mendapatkan bekal bahasa dalam pembelajaran formal, ia juga diaplikasikan dalam aktivitas sehari-hari. Seperti percakapan bahasa sesuai dengan jadwal yang telah ditentukan setiap jumat subuh, pidato dua bahasa dilaksanakan dua kali dalam seminggu. Semua kegiatan bahasa di pesantren Condong tidak terlepas dari pengajaran reward (penghargaan) dan punishment (hukuman). Bagi santri yang tidak bisa mengikuti aturan bahasa yang ditetapkan, hukuman akan berjalan tanpa terkecuali. Hal ini yang menjadi konsistennya condong dalam menerapkan sistem modern yang mewah dan berkualitas.

\section{KESIMPULAN}

Penelitian ini berpusat kepada salah satu pesantren di kota Tasikmalaya, pondok pesantren Riyadlul Ulum Wadda'wah Condong, yang telah berkiprah lama dalam nuansa modern. Pesantren Condong berhasil menerapkan tiga sistem pembelajaran yang meliputi kurikulum pendidikan nasional, kurikulum pesantren Modern Gontor, dan kurikulum tradisional. Apresiasi pesantren Condong terhadap kemodernan dibuktikan melalui penerapan bahasa asing yang diterapkan sampai saat ini. Condong sangat mengharapkan untuk menjadi pesantren andil terhadap kemajuan dan kemodernan namun tidak berarti lepas dari lima panca jiwa yang telah diterapkan oleh para dewan pesantren.

Lima panca jiwa tersebut terdiri dari jiwa keikhlasan, jiwa kesederhanaan, jiwa berdikari, jiwa ukhuwah diniyyah ( persaudaraan keagamaan), dan jiwa bebas. Semua panca jiwa ini menjadi kesatuan dan konsistensitas berdirinya pesantren Condong. Salah satunya dengan panca kebebasan yang digunakan oleh pesantren Condong melalui media bahasa asing. Penguatan dua bahasa ini bukan lagi menjadi budaya semata pengajaran di dalam kelas, namun menjadi sebuah keakraban agar para santri Condong mampu menghadapi peradaban yang dilapisi dengan kemodernan di zaman ini.

\footnotetext{
25 Salah satu penulis pernah mengenyam di pesantren Condong dan menjabat sebagai ketua bahasa di pesantren ini.
} 
Penelitian ini berhasil menemukan titik temu akar modernitas yang dipakai oleh pesantren Condong yaitu dengan meniru semangat kemodernan pesantren Darussalam Gontor. Ada beberapa hal yang pastinya memiliki perbedaan jauh diantaranya keduanya, salah satunya masih menerapkan sistem pembelajaran tradisional di pesantren Condong.

\section{DAFTAR PUSTAKA}

Azra, Azyumardi. Esai-Esai Intelektual Muslim Pendidikan Islam. Jakarta : Logos Wacana Ilmu, 1999.

Azra, Azyumardi. Surau, Pendidikan Islam Tradisional Dalam Transisi dan Modernisasi. Jakarta: Logos Wacana Ilmu, 2003.

Condong, Santri. Majalah Condong. Tasikmalaya: Condong Press, 2004.

Dhofier, Zamakhsyari. Tradisi Pesantren: Studi tentang Pandangan Hidup Kyai (Jakrta:LP3ES, 1984), 19.

Farida, Umma. "Radikalisme, Moderatisme, Dan Liberalisme Pesantren:Melacak Pemikiran dan Gerakan Keagamaan Pesantren di Era Globalisasi." Edukasia: Jurnal Penelitian Pendidikan Islam 10, 1 (2015).

Herman. "Sejarah Pesantren di Indonesia." Jurnal Al-Ta'dib 6, 2 (2013).

Muhakamurrohman, Ahmad. "Pesantren: Santri, Kiai, dan Tradisi." Jurnal Kebudayaan Islam 12, 2 (2014).

Madjid, Nurcholish. Modernisasi Pesantren. Jakarta: Mekarjaya 2001.Mulkhan, Abdul Munir. Nalar Spiritual Pendidikan, Solusi Problem Filosofis Pendidikan Islam. Yogyakarta: PT. Tiara Wacana Yogya, 2002.

Suharto, Ahmad. Melacak Akar Filosofis Pendidikan Gontor, (Kajian Metaforis Syajarah Thayyibah Gontor. Yogyakarta: Namela, 2017.

Syafe'i, Imam. "Pondok Pesantren: Lembaga Pendidikan Pembentukan Karakter." AlTadzkiyyah: Jurnal Pendidikan Islam 8, 1 (2017).

Yacub, Muhammad. Pondok Pesantren dan Pengembangan Masyarakat Desa. Bandung:Angkasa, 1993.

Zarkasyi, Abdullah Syukri. Gontor dan Pembaruan Pendidikan Pesantren. Jakarta: Raja Grafindo Persada 2005.

\section{Wawancara}

Falah, Diding Darul. Wawancara Tentang Sejarah Pesantren Condong di Pondok Pesantren Riyadlul Ulum Wadda'wah, ( 25 April 2020).

Farid, Mahmud. Wawancara di Pesantren Riyadlul Ulum Wadda'wah Tasikmalaya, (Tasikmalaya, 25 April 2020). 